\title{
Infectious Complications Following Kidney Transplantation-A Focus on Hepatitis C Infection, Cytomegalovirus Infection and Novel Developments in the Gut Microbiota
}

\author{
Samuel Chan ${ }^{1,2,3, *}$, Nicole M. Isbel ${ }^{1,2,3}$, Carmel M. Hawley ${ }^{1,2}$, Scott B. Campbell ${ }^{1,2,3}$, \\ Katrina L. Campbell 2,4 (D), Mark Morrison ${ }^{5}$, Ross S. Francis ${ }^{1,2,3}$, E. Geoffrey Playford ${ }^{2,6}$ \\ and David W. Johnson 1,2,3 \\ 1 Department of Nephrology, Princess Alexandra Hospital, Brisbane, QLD 4102, Australia; \\ nikky.isbel@health.qld.gov.au (N.M.I.); carmel.hawley@health.qld.gov.au (C.M.H.); \\ scott.campbell@health.qld.gov.au (S.B.C.); ross.francis@health.qld.gov.au (R.S.F.); \\ david.johnson2@health.qld.gov.au (D.W.J.) \\ 2 Australasian Kidney Trials Network, The University of Queensland, Brisbane, QLD 4102, Australia; \\ katrina.campbell@health.qld.gov.au (K.L.C.); geoffrey.playford@health.qld.gov.au (E.G.P.) \\ 3 Translational Research Institute, Brisbane, QLD 4102, Australia \\ 4 Centre for Applied Health Economics, Menzies Research Institute, Griffith University, \\ Brisbane, QLD 4102, Australia \\ 5 The University of Queensland Diamantina Institute, Faculty of Medicine, University of Queensland, \\ Woolloongabba, QLD 4102, Australia; m.morrison1@uq.edu.au \\ 6 Infection Management Services, Department of Microbiology, Princess Alexandra Hospital, \\ Brisbane, QLD 4102, Australia \\ * Correspondence: samuel.chan@uqconnect.edu.au; Tel.: +61-7-3176-5080
}

Received: 15 July 2019; Accepted: 30 September 2019; Published: 4 October 2019

\begin{abstract}
The incidence of infectious complications, compared with the general population and the pre-transplant status of the recipient, increases substantially following kidney transplantation, causing significant morbidity and mortality. The potent immunosuppressive therapy given to prevent graft rejection in kidney transplant recipients results in an increased susceptibility to a wide range of opportunistic infections including bacterial, viral and fungal infections. Over the last five years, several advances have occurred that may have changed the burden of infectious complications in kidney transplant recipients. Due to the availability of direct-acting antivirals to manage donor-derived hepatitis $C$ infection, this has opened the way for donors with hepatitis $C$ infection to be considered in the donation process. In addition, there have been the development of medications targeting the growing burden of resistant cytomegalovirus, as well as the discovery of the potentially important role of the gastrointestinal microbiota in the pathogenesis of post-transplant infection. In this narrative review, we will discuss these three advances and their potential implications for clinical practice.
\end{abstract}

Keywords: cytomegalovirus; direct acting antivirals; donor-derived infections; gastrointestinal microbiome; hepatitis C; knowledge acquisition; letermovir; kidney transplantation

\section{Introduction}

Kidney transplant recipients have a greatly increased risk of infection-related morbidity and mortality compared with the general population and the pre-transplant status of the recipient [1]. Worldwide, the incidence of infectious complications following kidney transplantation has been reported to range between 49 to $80 \%$ [1]. This increased risk is likely due to various immunosuppressive 
medications required to prevent allograft rejection [1,2]. Donor-transmitted infections, such as Hepatitis $\mathrm{C}$ virus (HCV), may also contribute to a heightened risk of infectious complications post-transplantation and have generally resulted in organs from high risk donors (e.g., HCV-positive) being excluded from transplant consideration. In addition to the virus itself, there is emerging data that HCV is associated with increased incidence of bacteremia, ventilator associated pneumonia and catheter-related bloodstream infection [3]. New treatments for donor-transmitted infections, such as direct acting antiviral drugs for HCV, substantially mitigate this risk [4]. Furthermore, cytomegalovirus (CMV) resistance appears to be emerging, which has necessitated the development of newer generation treatments to counteract this problem [5]. Finally, there is emerging evidence that kidney transplant recipients may have significantly altered gastrointestinal microbiota, which in turn may be associated with increased risks of infection as a result of transmural migration of bowel micro-organisms, altered immunosuppressive medication pharmacokinetics and progressive kidney disease [6-8]. This review will discuss these three recent, key, promising, innovative approaches to potentially mitigating infectious burden in kidney transplant recipients through direct acting antiviral drugs targeting HCV, new treatments for CMV resistance, and therapeutic manipulation of the gut microbiota.

\section{Changes in the Management to Donor-Derived Infections}

Donor-derived infections in kidney transplant recipients causes significant morbidity and mortality $[9,10]$. The incidence of donor-derived infections has been reported to be approximately $0.2 \%$ in solid organ transplantation [11]. Donor-derived infections may be classified into either expected or unexpected infections [12]. Expected donor-derived infections, namely CMV and Epstein-Barr Virus, may be identified by donor-recipient screening. Unexpected donor-derived infections are always a potential concern and cannot be completely excluded, and may include viral and bacterial infections such as urinary tract infections $[10,11]$. Of all the donor-derived infections reported, viral infections are most frequent $[9,10]$.

Hepatitis $\mathrm{C}$ virus $(\mathrm{HCV})$ is a well-recognized donor-derived infection. $\mathrm{HCV}$ positive donors were previously not offered to $\mathrm{HCV}$ uninfected recipients because of the increased mortality associated with liver and cardiovascular diseases [13,14]. Since 1995, 3502 HCV seropositive kidneys have been discarded in the United States of America, which is equivalent to a rate of $53.6 \%$ compared with $22.4 \%$ of HCV negative kidneys $[15,16]$. HCV seropositive but nucleic acid testing (NAT) negative donors are increasing in number and have been increasingly accepted as donors, with the caveat that a window-period is considered if the donor has had persistent risk behavior [17]. These donors also represent patients who have been successfully treated for HCV [17]. Recipients of these IgG positive NAT negative kidneys have been shown to become HCV IgG-positive post-transplant but not NAT-positive $[18,19]$. The likely explanation for this observation appears to be the transfer of HCV peptide with the organ or the transfer of passenger anti-HCV antibodies producing lymphocytes in the graft [20]. Nonetheless, the management of donor-derived HCV infection has been revolutionized through the development of direct-acting anti-HCV (DAA) drugs. HCV positive donors are a large pool, are usually younger compared with donors without $\mathrm{HCV}$ infection, and have fewer co-morbidities that are more likely to increase recipient and organ survival [13,14,21,22]. Recipients of HCV RNA positive donors or high risk donors (e.g., history of intravenous drug use, incarceration, less safe sexual practices, etc.,), particularly within the NAT window period, should have ongoing post-transplant surveillance for the appearance of $\mathrm{HCV}$ infection [23]. However, the exact timing of the surveillance is still being refined [23].

There are three main classes of DAAs which are classified based on the specific proteins that are targeted on the HCV [4-24] (Table 1). The protease inhibitors which act on the NS3 part of the HCV RNA include boceprevir, telaprevir, simeprevir, sunaprevir, grazoprevir and paritaprevir. The NS5A inhibitors, acting on the NS5A part of the HCV RNA, include daclatasvir, ledipasvir, ombitasvir, elbasvir and valpatasvir. The polymerase inhibitors, acting on the NS5B part of HCV RNA, include sofosbuvir and dasbuvir. These agents are orally administered, and the treatment duration varies 
between eight and twenty-four weeks [25,26]. Genotype I has the broadest DAA treatment options; however, all other genotypes have at least one DAA option. Suitable direct-acting antiviral agent combination regimens for each HCV genotype are depicted in Table 2.

Compared with traditional HCV treatments such as interferon alpha and ribavirin, DAAs have emerged as a highly effective therapeutic option for managing kidney transplant recipients who receive HCV RNA positive donor kidneys [4-24]. Interferon alpha is contraindicated in kidney transplant recipients because of the significant risk of provoking acute rejection [27]. In a study of 7344 adult patients with chronic HCV infection enrolled from 32 hepatology centers in France who were followed up for approximately 33 months, it was found that DAAs were associated with lower mortality (adjusted hazards ratio (HR) 0.48, 95\% CI 0.33-0.70) and hepatocellular carcinoma (adjusted HR 0.66, 95\% CI 0.46-0.93) rates and were not associated with decompensated cirrhosis (adjusted HR 1.14, 95\% CI 0.57-2.27) [28]. A Cochrane systematic review which included 138 randomized clinical trials and 25,232 participants, concluded that DAAs were relatively expensive and there was insufficient evidence to suggest that DAAs reduced mortality or other liver-related complications from chronic HCV [29]. However, this review has been heavily criticized for its interpretation and conclusions given its methodological flaws and the overall lack of clinical insight and knowledge of the natural history of HCV [29].

Table 1. Pharmacology of direct-acting antivirals agents.

\begin{tabular}{|c|c|c|c|c|c|c|}
\hline Agent Class & Example & Genotype & Adverse Events & Drug-Drug Interactions & Contraindications & $\begin{array}{c}\text { Probability } \\
\text { of Drug } \\
\text { Resistance }\end{array}$ \\
\hline $\begin{array}{l}\mathrm{NS} 3 / 4 \mathrm{~A} \\
\text { protease } \\
\text { inhibitors }\end{array}$ & $\begin{array}{c}\text { Boceprevir } \\
\text { Telaprevir } \\
\text { Simeprevir } \\
\text { Asunaprevir } \\
\text { Paritaprevir } \\
\text { Grazoprevir }\end{array}$ & Narrow & $\begin{array}{c}\text { Fatigue } \\
\text { Anemia } \\
\text { Nausea } \\
\text { Dysgeusia } \\
\text { Headache }\end{array}$ & $\begin{array}{l}\text { Multiple via CYP3A and } \\
\text { p-glycoprotein (e.g., } \\
\text { ritonavir, erythromycin, } \\
\text { rifampicin, efavirenz) }\end{array}$ & $\begin{array}{c}\text { Low creatinine } \\
\text { clearance; use of alpha-1 } \\
\text { adrenoreceptor } \\
\text { antagonists, } \\
\text { anticonvulsants, oral } \\
\text { contraceptive pills }\end{array}$ & High \\
\hline $\begin{array}{c}\text { NS5A } \\
\text { inhibitors }\end{array}$ & $\begin{array}{l}\text { Daclatasvir } \\
\text { Ledipasvir } \\
\text { Ombitasvir } \\
\text { Elbasvir } \\
\text { Velpatasvir }\end{array}$ & Medium & $\begin{array}{l}\text { Headache } \\
\text { Fatigue } \\
\text { Nausea } \\
\text { Diarrhea } \\
\text { Insomnia }\end{array}$ & $\begin{array}{l}\text { Minimal; case reports of } \\
\text { thyroid hormone, } \\
\text { dihydropyridines, alpha } \\
\text { and beta blockers, proton } \\
\text { pump inhibitors, statins }\end{array}$ & $\begin{array}{c}\text { Low creatinine } \\
\text { clearance; previous } \\
\text { Hepatitis B, use of } \\
\text { systemic steroids and } \\
\text { anticonvulsant therapy }\end{array}$ & Low \\
\hline $\begin{array}{c}\text { NS5B } \\
\text { polymerase } \\
\text { inhibitors }\end{array}$ & $\begin{array}{c}\text { Sofosbuvir } \\
\text { (nucleoside) } \\
\text { Dasabuvir } \\
\text { (non-nucleoside) }\end{array}$ & $\begin{array}{c}\text { Broad } \\
\text { (nucleoside) } \\
\text { Narrow } \\
\text { (non-nucleoside) }\end{array}$ & $\begin{array}{c}\text { Fatigue } \\
\text { Symptomatic } \\
\text { bradyarrhythmias }\end{array}$ & Minimal & $\begin{array}{l}\text { Low creatinine } \\
\text { clearance; use of } \\
\text { anticonvulsant and } \\
\text { antimicrobial therapy, } \\
\text { HIV protease inhibitor } \\
\text { therapy and herbal } \\
\text { supplements (e.g., } \\
\text { St John's Wort) }\end{array}$ & Low \\
\hline
\end{tabular}

Three studies have examined the efficacy and tolerability of utilizing HCV-positive donors (HCV RNA positive and NAT positive) into appropriately consented HCV-negative kidney transplant recipients (Table 3). The first study [30] was the Transplanting Hepatitis C Kidneys into Negative Kidney Recipients (THINKER) trial. In this open-label, singe-group pilot trial, $10 \mathrm{HCV}$ negative patients received kidneys from HCV positive donors ( 9 had genotype 1a infection), were administered elbasvir-grazoprevir from day 3 following transplantation, and were cured of HCV which was defined as a sustained virologic response 12 weeks after transplantation. The mean 6-month estimated glomerular filtration rate was $62.8 \mathrm{~mL} / \mathrm{min} / 1.73 \mathrm{~m}^{2}$. The $12-\mathrm{month}$ follow-up data on these 10 recipients, as well as 6-month follow-up data on additional $10 \mathrm{HCV}$-negative recipients of HCV-positive kidneys demonstrated that all 20 recipients had undetectable HCV RNA from 4 weeks until the end of follow-up of 6 months [31]. The THINKER participants had similar kidney graft function at 12 months compared to recipients of HCV-negative kidneys who met THINKER criteria and were matched for donor Kidney Donor Profile Index score (median 72.8 vs $67.2 \mathrm{~mL} / \mathrm{min} / 1.73 \mathrm{~m}^{2}$ ). Notably, one HCV-negative recipient developed subnephrotic range proteinuria without kidney function impairment and 5 recipients experienced transient serum aminotransferase elevations [31]. 
The third study was the Exploring Renal Transplants Using Hepatitis C Infected Donors for HCV Negative Recipients (EXPANDER) trial [32]. In this single center, single arm, open-label, non-randomized study, kidneys from $10 \mathrm{HCV}$-positive donors (genotypes 1-3) were transplanted into $10 \mathrm{HCV}$-negative recipients aged over 50 years and then treated for 12 weeks with grazoprevir, elbasvir and, for genotype 2 or 3 infections, sofosbuvir. At the end of the treatment period, no participants had detectable HCV RNA or treatment-related adverse drug reactions. Table 3 also illustrates studies [33-36] in which HCV RNA positive non-kidney solid organs were transplanted into HCV-negative recipients.

Table 2. Suitable direct-acting antiviral agent combination regimens for each Hepatitis $\mathrm{C}$ virus (HCV) genotype.

\begin{tabular}{cc}
\hline Genotype & Suitable Regimens \\
\hline Genotype 1 & Ledipasvir-sofosbuvir \\
& Sofosbuvir-velpatasvir \\
& Elbasvir-grazoprevir \\
& Glecaprevir-pibrentasvir \\
& Dasabuvir-omitasvir-paritaprevir-ritonavir \\
& Ombitasvir-paritaprevir-ritonavir-daclatasvir \\
\hline Genotype 2 & Sofosbuvir-velpatasvir \\
& Glecaprevir-pibrentsvir \\
& Dalatasvir-sofosbuvir \\
& Sofosbuvir-ribavirin \\
\hline Genotype 3 & Glecaprevir-pibrentasvir \\
& Sofosbuvir-velpatasvir \\
& Dalatasvir-sofosbuvir \\
& Sofosbuvir-ribavrin \\
\hline Genotype 4 & Ledipasvir-sofosbuvir \\
& Sofosbuvir-velpatasvir \\
& Elbsvir-grazoprevir \\
& Glecaprevir-pibretasvir \\
\hline & Ledipasvir-sofosbuvir \\
Genotype 5 and 6 & Sofosbuvir-velpatasvir \\
& Glecaprevir-pibrentasvir \\
\hline
\end{tabular}

Although these studies add to the evidence supporting the transplantation of HCV-positive kidneys in HCV-negative kidney recipients with subsequent treatment with DAAs, it should be noted that they were industry sponsored and limited by small sample sizes, single center study designs and short follow-up durations, which reduce the certainty of the evidence. A number of studies evaluating the efficacy, safety and tolerability of DAAs in seronegative patients of HCV positive donors are currently underway [37-39]. Furthermore, treatment protocols are still being developed and refined at the current time of writing this manuscript-the exact timing of introducing DAAs, the optimal duration of treatment, the appropriate monitoring requirements-are important questions and will require ongoing investigator-initiated multicenter studies to evaluate this. 
Table 3. Studies evaluating Hepatitis $C$ positive donors into Hepatitis $C$ negative recipients in transplantation.

\begin{tabular}{|c|c|c|c|c|c|c|c|}
\hline Study & Year & Study Design & $\mathbf{N}$ & $\begin{array}{c}\text { Mean Age of } \\
\text { Recipients (Years) }\end{array}$ & Organ Transplant & Intervention & Results \\
\hline Durand [31] & 2018 & $\begin{array}{l}\text { Open-label, } \\
\text { non-randomised trial }\end{array}$ & 10 & 71 (median) & Kidney & $\begin{array}{l}\text { Grazoprevir/elbasvir } \\
\text { (Genotype 1); } \\
\text { sofosbuvir added for } \\
\text { Genotype } 3\end{array}$ & $\begin{array}{c}\text { HCV RNA not detectable } \\
\text { Graft function stable } \\
\text { No treatment adverse effects } \\
\text { (sponsor: Merck Pharmaceuticals) }\end{array}$ \\
\hline Reese [30] & 2018 & $\begin{array}{l}\text { Open-label, } \\
\text { non-randomised trial }\end{array}$ & 20 & 56 & Kidney & $\begin{array}{l}\text { Grazoprevir/elbasvir } \\
\text { (Genotype 1) }\end{array}$ & $\begin{array}{c}\text { HCV RNA not detectable } \\
\text { Graft function stable } \\
\text { No treatment adverse effects } \\
\text { (sponsor: Merck Pharmaceuticals) }\end{array}$ \\
\hline Woolley [32] & 2019 & $\begin{array}{l}\text { Open-label, } \\
\text { non-randomised trial }\end{array}$ & 44 & 61 (median) & Heart and lung & $\begin{array}{l}4 \text { week-regimen of } \\
\text { sofosbuvir/velpatasvir }\end{array}$ & $\begin{array}{c}\text { 35/44 enrolled and completed } \\
6 \text { months follow-up (non-detectable } \\
\text { HCV RNA, stable graft function no } \\
\text { treatment adverse effects) }\end{array}$ \\
\hline Wadei [33] & 2019 & Case report & 1 & - & Liver & $\begin{array}{l}\text { Glecaprevir/pibentasvir } \\
\text { (delayed) }\end{array}$ & $\begin{array}{l}\text { Delay in direct-acting anti-HCV } \\
\text { drugs (DAA) resulted in severe } \\
\text { membranoproliferative } \\
\text { glomerulonephritis } \\
\text { requiring haemodialysis }\end{array}$ \\
\hline Abdelbasit [34] & 2018 & Case series & 5 & 47 & Lung & $\begin{array}{l}\text { Sofosbuvir/ledipasvir } \\
\text { (Genotype 1); } \\
\text { sofosbuvir/alpatasvir } \\
\text { (Genotype 2) }\end{array}$ & $\begin{array}{l}\text { HCV RNA not detectable } \\
\text { Graft function stable } \\
\text { No treatment adverse effects }\end{array}$ \\
\hline Schlendorf [35] & 2018 & $\begin{array}{l}\text { Open-label, } \\
\text { non-randomised trial }\end{array}$ & 13 & 53 & Heart & $\begin{array}{l}\text { Ledipasvir/sofosbuvir } \\
\text { (Genotype 1) and } \\
\text { Sofosbuvir/Velpatasivr } \\
\text { (Genotype 3) }\end{array}$ & $\begin{array}{c}\text { 12/13 undetectable HCV RNA } \\
1 \text { death (pulmonary emboli) } \\
\text { Graft function stable } \\
\text { No treatment adverse events }\end{array}$ \\
\hline Cotter [40] & 2019 & Registry & 2635 & 57 & Liver & $\begin{array}{l}\text { Various DAAs } \\
\text { (registry study) }\end{array}$ & $\begin{array}{l}\text { 3-year graft survival following use of } \\
\text { DAAs increased to } 88 \% \text { from } 79 \%\end{array}$ \\
\hline Axelrod [41,42] & 2018 & Registry & $\begin{array}{c}157,873 \text { kidney and } \\
58,509 \text { liver transplants }\end{array}$ & - & Kidney and liver & $\begin{array}{l}\text { Various DAAs } \\
\text { (registry study) }\end{array}$ & $\begin{array}{l}\text { Improvements in graft function and } \\
\text { death post DAA }\end{array}$ \\
\hline Cholankeril [41,42] & 2018 & Registry & 3855 & 58 & Liver & $\begin{array}{l}\text { Various DAAs } \\
\text { (registry study) }\end{array}$ & $\begin{array}{c}\text { 1-year post transplant survival } \\
\text { pre-DAA } 89.9 \% \text { vs } 91.9 \% \text { post DAA }\end{array}$ \\
\hline
\end{tabular}


A major consideration in using DAAs in kidney transplant recipients has been the optimal time to treat HCV infection. Problems related to limited drug access have emerged when using DAAs [43]. Severe membranoproliferative glomerulonephritis requiring haemodialysis, for example, has been reported in a 61-year old HCV-naïve diabetic male who received a liver transplant when glecaprevir/ pibrentasvir was unavailable until 24 days following transplantation [33].

Another important consideration in using DAAs is the high wholesale costs ranging from US $\$ 417$ (glecaprevir/pibrentasvir) to US $\$ 1125$ (ledipasvir-sofosbuvir) per day [43]. A study which used data from the Canada Health System created a Markov model to examine the cost-effectiveness of utilizing deceased HCV donors for kidney transplantation in HCV-negative recipients [44]. This study showed a cost-effectiveness ratio of $\$ 56,018$ per quality adjusted life years (QALY) from the payer perspective and $\$ 4647$ per QALY from the societal perspective, compared with recipients who would otherwise have remained on dialysis for an additional year [44].

Another issue emerging may be the potential risks of inducing resistance associated with transplanting different genotypes in kidney transplant recipients receiving DAAs. Resistance may occur particularly when therapeutics levels are suboptimal, thus creating selective pressure for resistant $\mathrm{HCV}$ to emerge as the dominant species [45]. A study undertaken in Brazil involving 76 patients, of whom 39 were kidney transplant recipients and 37 were on chronic haemodialysis, examined the prevalence of resistance-associated substitutions to DAAs and found that the overall prevalence of resistance was $38.2 \%$ with substitution resistance detected in NS3A (17.8\%), NS5A (21.9\%) and NS5B (8.4\%) inhibitors [46]. Resistance substitutions were higher in Genotype 1a (42.9\%) compared with Genotype $1 \mathrm{~b}(32.4 \%)(p=0.35)$ [46]. However, this study was limited by the fact that patients were restricted to Genotype 1 and the sample size was small. More studies will be required to further elucidate the resistance patterns of DAAs.

In addition to being effective in the treatment of recipients of kidneys from HCV-positive donors, DAAs appear also to be effective for the treatment of $\mathrm{HCV}$-positive recipients. A retrospective Italian study a sustained virologic response in 12 (92\%) of 13 HCV RNA-positive kidney transplant recipients [47]. There is ongoing debate regarding whether it is better to treat HCV-positive individuals with end-stage kidney disease before or after a kidney transplant [48]. Early treatment prior to kidney transplantation may reduce the risks of hepatic complications, dialysis transmission of $\mathrm{HCV}$, post-transplant glomerulonephritis and post-transplant diabetes mellitus, whilst treatment following kidney transplantation affords the patient the opportunity to receive a kidney from a HCV-positive donor thereby shortening transplant waiting time [48]. Our practice is to treat $\mathrm{HCV}$-infected individuals as soon as possible prior to kidney transplantation.

\section{New Approaches to the Management of Infections in the Era of Antimicrobial Resistance}

A paradigm of antimicrobial resistance developing in kidney transplant recipients involves cytomegalovirus (CMV), which is an opportunistic viral pathogen causing infection and disease with significant morbidity and mortality. Indeed, $60 \%$ of kidney transplant recipients will have an active CMV viraemia, and more than $20 \%$ will develop symptomatic disease [49-52]. Infection with CMV usually develops when prophylaxis is ceased and may cause end-organ damage such as hepatitis, pancreatitis or pneumonitis [50,51]. Four antiviral therapies are currently marketed for either the prophylaxis and/or treatment of CMV infection: ganciclovir, the ganciclovir prodrug (valganciclovir), foscarnet and cidofovir.

According to current guidelines, options for CMV prophylaxis include oral valgancyclovir, oral valaciclovir, and intravenous ganciclovir [53]. The addition of anti-CMV immunoglobulin to these agents has not been shown to have any additional benefit. Although valganciclovir is used most frequently in many kidney transplant units because of its oral formulation, it is limited by high costs and occasional difficulties with access. Intravenous ganciclovir, on the other hand, is cheaper and more readily available but limited due to the difficulties in giving it in the home environment [53]. The recommended dosage for CMV prophylaxis is $900 \mathrm{mg}$ for oral valgancyclovir daily and $3200 \mathrm{mg}$ for 
oral valaciclovir daily for 3 months in CMV seropositive recipients, adjusted for kidney function [53]. Some kidney transplant units have used a lower dose of valganciclovir for CMV prophylaxis which may in turn lead to resistance; however, more studies will be required to assess the efficacy and potential resistance patterns of valgancyclovir at a lower dose [53]. For kidney transplants involving CMV seromismatch (i.e., donor seropositive, recipient seronegative), a duration of 6 months is recommended. The alternative strategy to prophylaxis for prevention of CMV disease is routine viral load monitoring and prescribing antiviral treatment when viral loads increase significantly regardless of whether or not the individual is symptomatic (pre-emptive treatment). Whilst the Updated International Consensus Guidelines on the Management of Cytomegalovirus in Solid-Organ Transplantation indicate that there is moderate evidence supporting this approach [53], a previous Cochrane review of the efficacy of pre-emptive therapy compared to prophylaxis concluded that the evidence was uncertain due to the presence of appreciable study heterogeneity $[53,54]$. Monitoring of viral loads for up to 6 months following CMV prophylaxis in patients with established risk factors for CMV should occur [53].

Mutations in UL-97 and UL-54 mediate CMV resistance to the above therapies [53,55-57]. The incidence of CMV resistance varies between $2 \%$ to $7 \%$ [51,52]. Risk factors include CMV donor positive/recipient negative serostatus, potent immunosuppressive use, induction therapy with anti-thymocyte globulin, high viral loads and prolonged duration of treatment with suboptimal drug levels [51,52]. A few different antiviral therapies, such as letermovir and maribavir, are currently being studied to mitigate CMV resistance [53,55-58]. The pharmacology of these two therapies are summarized in Table 4. The adoptive transfer of autologous or third-party CMV-reactive T-cells is also being examined as a potential therapy.

Table 4. Pharmacology of letermovir and maribavir.

\begin{tabular}{ccccc}
\hline Medication & Mechanism of Action & Adverse Events & Resistance Patterns & $\begin{array}{c}\text { Drug-Drug } \\
\text { Interactions }\end{array}$ \\
\hline Letermovir & $\begin{array}{c}\text { Inhibits viral terminase } \\
\text { complex (UL51/JL56/UL89) }\end{array}$ & $\begin{array}{c}\text { Nausea, diarrhea, vomiting, } \\
\text { peripheral edema, cough, } \\
\text { headache, fatigue and } \\
\text { abdominal pain }\end{array}$ & None noted & $\begin{array}{c}\text { None known, } \\
\text { possibly with } \\
\text { ciclosporin }\end{array}$ \\
\hline $\begin{array}{c}\text { Inhibits CM UL97 } \\
\text { Maribavir } \\
\text { serine/threonine kinase by } \\
\text { competitively inhibiting the } \\
\text { binding of ATP to the kinase } \\
\text { ATP-binding site }\end{array}$ & $\begin{array}{c}\text { Gastrointestinal disorders } \\
\text { (diarrhea, dysgeusia, } \\
\text { nausea, vomiting) }\end{array}$ & $\begin{array}{c}\text { Emerging (T409M and } \\
\text { H411Y) }\end{array}$ & $\begin{array}{c}\text { CYP3A4 } \\
\text { P-glycoprotein }\end{array}$ \\
\hline
\end{tabular}

Letermovir is a new non-nucleoside CMV inhibitor which targets the viral terminase complex [59,60], and has been demonstrated to inhibit CMV in both in vitro and in vivo preclinical studies $[60,61]$. In a phase 3 , double-blind, randomized controlled trial of letermovir versus placebo in 565 CMV-seropositive adult hematopoietic-cell transplant recipients, 495 participants had undetectable levels of CMV DNA at baseline. Amongst these individuals, the occurrence of clinically significant CMV infection by 24 weeks was significantly lower in those receiving letermovir compared with placebo (38\% vs. 61\%, respectively, $p<0.001)$. Myelotoxic and nephrotoxic adverse effects were comparable in both groups [62]. Similar findings have been reported in kidney transplant recipients. In a multi-center, open-label, randomized controlled trial of letermovir (40 mg twice a day or $80 \mathrm{mg}$ once a day) or usual care in 27 kidney transplant recipients with active CMV replication, viral clearance was more often achieved in the combined letermovir groups ( 6 out of $12,50 \%$ ) than the usual care group (2 out of 7, 29\%) [62]. There were no reported relapses in CMV during this trial [62].

A case report by Kau et al. reported the first successful treatment of multidrug-resistant CMV with letermovir in a 39-year-old male lung transplant recipient who developed severe CMV pneumonitis, retinitis and colitis that was refractory to ganciclovir, foscarnet, CMV hyperimmune globulin, cidofovir, artemether/lumefantrine and leflunomide [63]. CMV genotype analysis demonstrated A594T and 
C603W UL97 mutations. Following introduction of letermovir in combination with immunosuppression reduction, the patient made a rapid recovery.

On the contrary, there has been some recent literature regarding potential resistance in letermovir. A case series reported 2 heart and 2 lung transplant adult patients who received letermovir for treatment of ganciclovir-resistant CMV disease after failing therapy with ganciclovir and valganciclovir, and developing nephrotoxicity from foscarnet [64]. Two of the 4 patients from this study had CMV retinitis proven by CMV PCR obtained via anterior chamber paracentesis and the other 2 patients had funduscopic examination consistent with retinitis. Induction letermovir doses occurred at $720 \mathrm{mg}$ and in one patient titrated to $960 \mathrm{mg}$ and all 4 patients had clinical improvement in retinitis [64]. However, 3 of the 4 patients failed to achieve sustained virologic suppression, raising potential concerns for letermovir resistance. Genotypic assessment demonstrated UL56 mutations. Virologic suppression occurred in the 3 patients when transitioned back to original therapy. However, none of the patients reported adverse effects secondary to letermovir [64]. Overall, there is some evidence that letermovir may show promise as a treatment for CMV resistance. However, the role of letermovir in patients with CMV disease who cannot tolerate currently available therapies remains to be determined. Moreover, the dosing, efficacy and potential resistance patterns of letermovir in the management of CMV resistance requires further evaluation.

In addition to letermovir, maribavir, an inhibitor of UL-97 viral kinase, is also currently under clinical trials for managing CMV resistance, although results are still in the preliminary phase [65]. Papanicoloaou et al. [65] conducted a randomized, double-blinded, dose-ranging phase 2 study of 3 different doses of maribavir ( $400 \mathrm{mg}, 800 \mathrm{mg}$ or $1200 \mathrm{mg}$ twice daily) for up to 24 weeks in 47 hematopoietic-cell and 73 solid-organ transplant recipients (including 30 kidney transplant recipients) with active CMV infection that was refractory or resistant to ganciclovir, valganciclovir, foscarnet and cidofovir (defined as failure to achieve at least a $1 \log 10$ decrease in CMV DNA viral load after at least 2 weeks of treatment). Overall, $67 \%$ (95\% CI 57-57\%) of patients achieved undetectable CMV DNA within 6 weeks of maribavir treatment, with similar results observed in the 3 dosage groups (400 mg 70\%, $800 \mathrm{mg} \mathrm{63 \% ,} 1200 \mathrm{mg} \mathrm{68 \% ).} \mathrm{Balanced} \mathrm{against} \mathrm{these} \mathrm{benefits,} \mathrm{68 \%} \mathrm{developed} \mathrm{adverse}$ events, including dysgeusia $(65 \%)$ and neutropenia $(11 \%)$, which led to maribavir discontinuation in $34 \%$ of patients. Recurrent CMV infections occurred in $25 \%$ and 4 patients $(3.3 \%$ ) died due to CMV.

Another important investigation conducted by a French group included 12 patients ( 3 bone marrow recipients and 9 solid organ transplant recipients) with CMV resistance, showed that half the patients responded to maribavir when trialed at $800 \mathrm{mg}$ daily doses [66]. Although maribavir shows promise in the treatment of resistant $\mathrm{CMV}$ infections, concerns regarding maribavir resistance have emerged [65] with T409M and H411Y being reported as potential gene mutation markers [67]. Other studies have raised concerns regarding the efficacy of maribavir, with one randomized, double-blinded, multicenter controlled trial of 303 liver transplant recipients showing that maribavir $100 \mathrm{mg}$ twice daily was ineffective at preventing CMV infections [68]. Collectively, these findings highlight that further studies are required to determine the efficacy, tolerability and potential for resistance in using maribavir for the management of resistant CMV infections in kidney transplant recipients.

An alternative approach to the management of CMV resistance has been the use of adoptive T-cell therapy with CMV-reactive T-cells [69-71]. CMV control is critically dependent on effective T cell immunity. In a prospective, multicenter, single-arm, open-label, non-randomized phase 1 study [71] of in vitro-expanded autologous CMV-specific T cell therapy in 13 solid organ transplant recipients with recurrent or ganciclovir-resistant CMV infection, 11 (84\%) displayed either complete resolution or reduction in DNAemia. It has also been demonstrated that multiple infusions may be required, particularly if the initial response was suboptimal or if rebound CMV viraemia occurred $[69,70]$. Other groups have developed multivirus reactive $T$ cell protocols typically including viruses such as CMV, Epstein-Barr virus, BK virus and adenovirus [72-74]. Difficulties inherent with such treatments include high cost, the appreciable time taken to adequately generate the T-cells for transfusion, and the requirement for significant patient commitment to adhere to hospital appointments for treatment 
success $[69,70]$. The potential benefits of adoptive T-cell therapy also need to be balanced against the potential associated risks of treatment. For example, graft failure $(n=1,2 \%)$ and graft-associated thrombotic microangiopathy $(n=1,2 \%)$ have been reported in a group of 50 allogenic stem cell transplant patients who were given a single dose of CMV-specific T-cells [75]. Given the limited sample size in the above studies, more research is required to assess the robustness of using autologous T-cell therapy in CMV resistance.

\section{Emergence of Gastrointestinal Microbiota and Transplant Associated Infections}

In recent times, it has been recognized that a major, potential source of infection in immunocompromised individuals is the gut microbiota, which is comprised of bacteria, archaea, fungi, protozoa, and their respective viruses [76-78]. A large number of observational and cross-sectional studies have shown that the gut microbiota is a functional and dynamic interface linked with immune regulation, metabolic modulation, food digestion, angiogenesis promotion, gut epithelial health, energy homeostasis, neurobehavioural development and drug absorption, metabolism and disposition [79-81]. Additionally, antibiotic use, psychosocial and physical stress, radiation, dietary changes and various disease states are all known to be associated with alterations in the taxonomic and functional properties of the gut microbiota [82]. These changes are generically referred to as "dysbiosis". In the setting of gut dysbiosis, transmural migration of gut micro-organisms and/or their toxic products (endotoxins and uraemic toxins such as indoxyl sulphate and p-cresyl sulphate) may lead to infection, inflammation, endotoxaemia, and the progression of kidney disease [83-86]. Products of the gut microbiota (e.g., peptidoglycans, polysaccharide A) also interact with the enteric immune system to stimulate both innate and adaptive immune mechanisms, and antigen cross-reactivity may promote alloimmunity and rejection through molecular mimicry [87].

Several studies have demonstrated that the gut microbiota may be significantly altered in the setting of kidney transplantation and play an important role in post-transplant outcomes. Gut microbiota in kidney transplant recipients can be potentially modified by immunosuppression, antibiotic administration, dietary changes, altered bowel mobility and even transplantation of microbiota via kidney and kidney-pancreas allografts $[82,88,89]$. In a pilot study in which microbiota profiles were examined in serial fecal specimens from 26 kidney transplant recipients during the first 3 months post-transplant using polymerase chain reaction (PCR) amplification of the 16S rRNA V4-V5 variable region, Lee et al. demonstrated significant changes in gut microbiota profiles compared to pre-transplantation [6]. Importantly, higher fecal abundance of Enterococcus was associated with Enterococcus urinary tract infection and pre-dated the occurrence of this infection by up to 39 days. Median fecal abundance of Enterococcus in transplant recipients who did and did not develop Enterococcus urinary tract infection was $24 \%$ and $0 \%$, respectively $(p=0.005$ ). The group also demonstrated that acute rejection was associated with higher fecal abundance of Enterococcus, Clostridium tertium, Anaerofilum and Lactobacillales, and lower fecal abundance of Bacteroides, Ruminococcus, Lachnospiraceae, Clostridiales, Blautia, and Eubacterium dolichum. Another group also reported associations between fecal abundance of micro-organisms and the occurrence of infection and acute rejection in kidney transplant recipients [90]. Lee et al. subsequently reported that post-transplant diarrhea was associated with reductions in fecal diversity measures and specifically, decreases in the relative abundance of commensal bacteria such as Ruminococcus, Dorea, Coprococcus and Bacteroides spp., rather than with common infectious diarrheal pathogens [7]. Finally, another study of serial fecal specimens in 19 kidney transplant recipients during the first post-transplant month has demonstrated that alterations in gut microbiota profiles might be associated with altered immunosuppressant medication pharmacokinetics [8]. Specifically, the relative abundance of one bacterium, Faecalibacterium prausnitzii, was significantly greater in kidney transplant recipients who ultimately also required at least a $50 \%$ increase in tacrolimus dosing over the first month to achieve a target serum level of $8-10 \mathrm{ng} / \mathrm{mL}$, when compared to recipients who did not require such a dosage escalation $(11.8 \%$ versus $0.8 \%$, respectively, $p=0.002)$ [8]. Taken together, these preliminary findings 
involving relatively small patient numbers suggest that kidney transplantation results in significant changes in the gut microbiota composition which in turn are associated with important surrogate and clinical post-transplant outcomes including infection, altered serum immunosuppressant medication levels, acute rejection and post-transplant diarrhea.

Manipulation of the gut microbiota through nutritional interventions, such as prebiotics, probiotics, and synbiotics, may therefore represent a novel approach to mitigating infection and other transplant complications such as rejection and post-transplant diarrhea [91,92]. Although there have been no studies that have specifically addressed nutritional interventions targeting the gut microbiota in kidney transplant recipients, a meta-analysis of four studies (3 randomized controlled trials and 1 historically controlled trial) involving 246 liver transplant recipients has shown that administration of prebiotics and probiotics resulted in appreciably reduced rates of overall infection (relative risk (RR) $0.21,95 \%$ CI $0.11-0.41, \mathrm{I} 2 \mathrm{1} \%$ ), urinary tract infection (RR 0.14, 95\% CI 0.04-0.47, I2 0\%) and intra-abdominal infection (RR 0.27, 95\% CI 0.09-0.78, I2 0\%) [93]. The interpretative strength of this review is limited by the small number of available studies, the heterogeneity of the prebiotic and probiotic interventions, small patient numbers, short follow-up durations, inclusion of a non-randomized controlled trial and low certainty of the evidence. Currently, the safety of probiotics in the kidney transplant population is uncertain, and their use is therefore not routinely recommended at the present time [94].

Recently, there has been evidence emerging that fecal microbiota transplantation (FMT) may be an effective option for manipulating the gut microbiota, particularly in the setting of recurrent Clostridium difficile infection. In a retrospective singe-center chart review of 35 patients with recurrent Clostridium difficile who underwent FMT in the United States of America, 85.7\% $(n=30)$ reported resolution of symptoms approximately 6 to 8 weeks post-transplant [95]. Adverse effects were monitored by the research team, but none were reported in the final study [95]. Eight of the 35 recipients were reportedly receiving immunosuppressive therapy, although the type and dosage of such therapy was not specified [95]. A subsequent systematic review and meta-analysis of 54 non-randomized studies of FMT in 303 immunocompromised patients with recurrent Clostridium difficile infection reported success rates of $87 \%$ on first treatment [96]. FMT has also been evaluated as a potential therapy for steroid-resistant acute graft-versus-host disease in the setting of stem cell transplantation [97] FMT was safely tolerated and effective in 4 patients, with 3 experiencing a complete response and one having a partial response. Although these results appear to be promising, the role of FMT in manipulation of the gut microbiota in kidney transplant recipients has yet to be determined.

Indeed, examining the role(s) of the gut microbiota in the pathogenesis of infections in transplant recipients present considerable challenges. There will always be significant heterogeneity amongst transplant recipients, attributable to their previous medical history including hospital admissions, prior exposure to various antibiotics prior to transplantation, as well as immunosuppressive therapy and antimicrobial prophylaxis. However, the findings from the small number of studies to date do suggest that adequately powered, well-designed, and multi-center randomized controlled trials are justified to determine whether and how variations in the gut microbiota can be translated into low cost, prognostic and/or therapeutic approaches that reduce post-transplant infections, as well as to maximize the use of immunosuppressive therapy post-transplantation (e.g., tacrolimus).

\section{Conclusions}

Over the last five years, ongoing research has led to significant advancements in the field of kidney transplant infectious disease medicine. The development of new approaches to manage donor-derived infections, such as Hepatitis C, have allowed expansion of the deceased kidney donor pool to include donors that were previously considered unsuitable. At the same time, new antiviral agents, such as letermovir and maribavir, are currently being trialed to combat growing CMV resistance. Recent evidence has also suggested that the gut microbiota, which changes appreciably following kidney transplantation, might represent a significant source of post-transplant infections, and contribute to altered immunosuppressive agent pharmacokinetics, acute rejection and post-transplant diarrhea. 
These outcomes may be mitigated by nutritional interventions (e.g., pre, pro- and synbiotics) and fecal microbiota transplantation, although further studies are required to comprehensively evaluate their safety and efficacy. These developments have generated considerable research interest and endeavor in the transplant infectious disease field and offer new opportunities to alleviate infectious morbidity and mortality in kidney transplant patients.

Author Contributions: S.C. drafted the manuscript. N.M.I., C.M.H., S.B.C. K.L.C., M.M., R.S.F., E.G.P. and D.W.J. provided critical analysis to the paper. All authors read and approved the final manuscript.

Funding: This research received no external funding.

Acknowledgments: Research (MM) was carried out at the Translational Research (TRI) Institute, Woolloongabba, Queensland, 4102, Australia. The TRI is supported by a grant from the Australian Government. However, in relation to this specific paper, neither cash funds were provided, nor TRI core facilities were used, to produce the information included in this narrative review.

Conflicts of Interest: Samuel Chan is supported by the Australian National Health and Medical Research Council (NHMRC) Postgraduate Scholarship, the Microba recipient grant, the Metro South Research Support Scheme, and the Royal Australasian College of Physicians NHMRC Research Excellence top-up award. Furthermore, Dr Chan is a current recipient of the 2018 Sir Gustav Nossal NHMRC Postgraduate Scholarship award. David Johnson has received consultancy fees, research grants, speaker's honoraria and travel sponsorships from Baxter Healthcare and Fresenius Medical Care. He has received consultancy fees from Astra Zeneca and travel sponsorships from Amgen. He is a current recipient of an Australian NHMRC Practitioner Fellowship. Carmel Hawley is the recipient of research grants paid to her institution from Baxter Healthcare and Fresenius Medical Care and from Otsuka, Janssen and GlaxoSmithKLline for trial steering committee activities, paid to her institution. Nicole Isbel has received consultancy fees and speaker's honoraria from Alexion Pharmaceuticals, Novo Nordisk and Amgen. The remaining authors have no conflicts of interest to declare with respect to the context and scope of this manuscript.

\section{Abbreviations}

$\begin{array}{ll}\text { CDI } & \text { Clostridium difficile infection } \\ \text { CMV } & \text { Cytomegalovirus } \\ \text { DAA } & \text { Direct-acting antivirals } \\ \text { EXPANDER } & \text { Exploring Renal Transplants Using Hepatitis C Infected Donors for HCV Negative Recipients } \\ \text { HCV } & \text { Hepatitis C virus } \\ \text { HR } & \text { Hazards Ratio } \\ \text { NAT } & \text { Nucleic Acid Testing } \\ \text { QALY } & \text { Quality Adjusted Life Years } \\ \text { PCR } & \text { Polymerase Chain Reaction } \\ \text { THINKER } & \text { Transplanting HCV-infected Kidneys into Negative Kidney Recipients }\end{array}$

\section{References}

1. Fishman, J.A. Infection in organ transplantation. Am. J. Transplant. 2017, 17, 856-879. [CrossRef] [PubMed]

2. Kinnunen, S.; Karhapää, P.; Juutilainen, A.; Finne, P.; Helanterä, I. Secular Trends in Infection-Related Mortality after Kidney Transplantation. Clin. J. Am. Soc. Nephrol. 2018, 13, 755. [CrossRef] [PubMed]

3. Kueht, M.; Bebko, S.; Helmick, R.; Awad, S. Hepatitis C status and infectious complications in the surgical intensive care unit: A retrospective analysis of 1,941 consecutive patients. Am. J. Surg. 2016, 211, 1064-1070. [CrossRef]

4. Liang, T.J.; Ghany, M.G. Current and Future Therapies for Hepatitis C Virus Infection. N. Engl. J. Med. 2013, 368, 1907-1917. [CrossRef] [PubMed]

5. Piret, J.; Boivin, G. Clinical Development of Letermovir and Maribavir: Overview of Human Cytomegalovirus Drug Resistance. Antiviral Res. 2019, 163, 95-105. [CrossRef] [PubMed]

6. Lee, J.R.; Muthukumar, T.; Dadhania, D.; Toussaint, N.C.; Ling, L.; Pamer, E.; Suthanthiran, M. Gut microbial community structure and complications following kidney transplantation: A pilot study. Transplantation 2014, 98, 697 . 
7. Lee, J.; Magruder, M.; Zhang, L.; Westblade, L.; Satlin, M.; Robertson, A.; Edusei, E.; Crawford, C.; Ling, L.; Taur, Y.; et al. Gut microbiota dysbiosis and diarrhea in kidney transplant recipients. Am. J. Transplant. 2019, 19, 488-500. [CrossRef]

8. Lee, J.; Muthukumar, T.; Dadhania, D.; Taur, Y.; Jenq, R.; Toussaint, N.; Ling, L.; Pamer, E.; Suthanthiran, M. Gut Microbiota and Tacrolimus Dosing in Kidney Transplantation. PLoS ONE 2015, 10, e0122399. [CrossRef]

9. Ison, M.G.; Nalesnik, M.A. An update on donor-derived disease transmission in organ transplantation. Am. J. Transplant. 2011, 11, 1123-1130. [CrossRef]

10. Shingde, R.; Habachou, L.I.; Calisa, V.; Craig, J.C.; Tong, A.; Chen, S.C.A.; Wong, G. Unexpected donor-derived infectious transmissions by kidney transplantation: A systematic review. Transpl. Infect. Dis. 2018, 20, e12851. [CrossRef]

11. Ison, M.G.; Grossi, P. Donor-Derived Infections in Solid Organ Transplantation. Am. J. Transplant. 2013, 13, 22-30. [CrossRef] [PubMed]

12. Garzoni, C.; Ison, M.G. Uniform Definitions for Donor-Derived Infectious Disease Transmissions in Solid Organ Transplantation. Transplantation 2011, 92, 1297-1300. [CrossRef] [PubMed]

13. Levitsky, J.; Formica, R.N.; Bloom, R.D.; Charlton, M.; Curry, M.; Friedewald, J.; Friedman, J.; Goldberg, D.; Hall, S.; Ison, M.; et al. The American Society of Transplantation Consensus Conference on the Use of Hepatitis C Viremic Donors in Solid Organ Transplantation. Am. J. Transplant. 2017, 17, 2790-2802. [CrossRef] [PubMed]

14. Goldberg, D.S.; Blumberg, E.; McCauley, M.; Abt, P.; Levine, M. Improving Organ Utilization to Help Overcome the Tragedies of the Opioid Epidemic. Am. J. Transplant. 2016, 16, 2836-2841. [CrossRef] [PubMed]

15. Armando, C.; Evangelista, S.; Massimiliano, C.; Silvia, A.; Gaia, P.; Paola, I.; Maria, C.; Gianluca, M.; Nicola, C.; Concetta Anna, D.; et al. Eradication of HCV Infection with the Direct-Acting Antiviral Therapy in Renal Allograft Recipients. BioMed Res. Int. 2019, 2019, 4674560.

16. Bowring, M.G.; Kucirka, L.M.; Massie, A.B.; Luo, X.; Cameron, A.; Sulkowski, M.; Rakestraw, K.; Gurakar, A.; Kuo, I.; Segev, D.L.; et al. Changes in Utilization and Discard of Hepatitis C-Infected Donor Livers in the Recent Era. Am. J. Transplant. 2017, 17, 519-527. [CrossRef] [PubMed]

17. Bari, K.; Luckett, K.; Kaiser, T.; Diwan, T.; Cuffy, M.; Schoech, M.R.; Safdar, K.; Blackard, J.T.; Apewokin, S.; Paterno, F; et al. Hepatitis $C$ transmission from seropositive, nonviremic donors to non-hepatitis $C$ liver transplant recipients. Hepatology 2018, 67, 1673. [CrossRef]

18. Agarwal, N.; Davis, R.J.; Gracey, D.M.; Wong, G.; Kable, K.; Wong, J.K.W.; Nankivell, B.J.; Strasser, S.; Wyburn, K. Detection of hepatitis $C$ antibodies without viral transmission in hepatitis C-negative recipients receiving kidneys from hepatitis C-positive donors treated with direct-acting antiviral therapy. Transplantation 2018, 102, e121-e122. [CrossRef]

19. De Vera, M.E.; Volk, M.L.; Ncube, Z.; Blais, S.; Robinson, M.; Allen, N.; Evans, R.; Weissman, J.; Baron, P.; Kore, A.; et al. Transplantation of hepatitis $\mathrm{C}$ virus (HCV) antibody positive, nucleic acid test negative donor kidneys to HCV negative patients frequently results in seroconversion but not HCV viremia. Am. J. Transplant. 2018, 18, 2451-2456. [CrossRef]

20. Porrett, P.M.; Reese, P.P.; Holzmayer, V.; Coller, K.E.; Kuhns, M.; Van Deerlin, V.M.; Gentile, C.; Smith, J.R.; Sicilia, A.; Woodards, A.; et al. Early emergence of anti-HCV antibody implicates donor origin in recipients of an HCV-infected organ. Am. J. Transplant. 2019, 19, 2525-2532. [CrossRef]

21. Durand, C.M.; Bowring, M.G.; Thomas, A.G.; Kucirka, L.M.; Massie, A.B.; Cameron, A.; Desai, N.M.; Sulkowski, M.; Segev, D.L. The Drug Overdose Epidemic and Deceased-Donor Transplantation in the United States: A National Registry Study. Ann. Intern. Med. 2018, 168, 702-711. [CrossRef] [PubMed]

22. Trotter, P.B.; Summers, D.M.; Ushiro-Lumb, I.; Robb, M.; Bradley, J.A.; Powell, J.; Watson, C.J.; Neuberger, J. Use of organs from hepatitis $C$ virus-positive donors for uninfected recipients: A potential cost-effective approach to save lives? Transplantation 2018, 102, 664-672. [CrossRef] [PubMed]

23. White, S.L.; Rawlinson, W.; Boan, P.; Sheppeard, V.; Wong, G.; Waller, K.; Opdam, H.; Kaldor, J.; Fink, M.; Verran, D.; et al. Infectious Disease Transmission in Solid Organ Transplantation: Donor Evaluation, Recipient Risk, and Outcomes of Transmission. Transplant. Direct 2019, 5, e416. [CrossRef] [PubMed]

24. Geddawy, A.; Ibrahim, Y.F.; Elbahie, N.M.; Ibrahim, M.A. Direct Acting Anti-hepatitis C Virus Drugs: Clinical Pharmacology and Future Direction. J. Transl. Intern. Med. 2017, 5, 8-17. [CrossRef] [PubMed] 
25. AASLD/IDSA HCV Guidance Panel. Hepatitis C guidance: AASLD-IDSA recommendations for testing, managing, and treating adults infected with hepatitis C virus. Hepatology 2015, 62, 932-954. [CrossRef] [PubMed]

26. Carbognin, S.J.; Solomon, N.M.; Yeo, F.E.; Swanson, S.J.; Bohen, E.M.; Koff, J.M.; Sabnis, S.G.; Abbott, K.C. Acute Renal Allograft Rejection Following Pegylated IFN- $\alpha$ Treatment for Chronic HCV in a Repeat Allograft Recipient on Hemodialysis: A Case Report. Am. J. Transplant. 2006, 6, 1746-1751. [CrossRef] [PubMed]

27. Carrat, F.; Fontaine, H.; Dorival, C.; Simony, M.; Diallo, A.; Hezode, C.; De Ledinghen, V.; Larrey, D.; Haour, G.; Bronowicki, J.P.; et al. Clinical outcomes in patients with chronic hepatitis C after direct-acting antiviral treatment: A prospective cohort study. Lancet 2019, 393, 1453-1464. [CrossRef]

28. Jakobsen, J.C.; Nielsen, E.E.; Koretz, R.L.; Gluud, C. Do direct acting antivirals cure chronic hepatitis C? BMJ 2018, 361, k1382. [CrossRef]

29. Goldberg, D.S.; Abt, P.L.; Blumberg, E.A.; Van Deerlin, V.M.; Levine, M.; Reddy, K.R.; Bloom, R.D.; Nazarian, S.M.; Sawinski, D.; Porrett, P.; et al. Trial of Transplantation of HCV-Infected Kidneys into Uninfected Recipients. N. Engl. J. Med. 2017, 376, 2394-2395. [CrossRef]

30. Reese, P.P.; Abt, P.L.; Blumberg, E.A.; Van Deerlin, V.M.; Bloom, R.D.; Potluri, V.S.; Levine, M.; Porrett, P.; Sawinski, D.; Nazarian, S.M.; et al. Twelve-Month Outcomes After Transplant of Hepatitis C-Infected Kidneys Into Uninfected Recipients: A Single-Group Trial. Ann. Intern. Med. 2018, 169, 273-281. [CrossRef]

31. Durand, C.M.; Bowring, M.G.; Brown, D.M.; Chattergoon, M.A.; Massaccesi, G.; Bair, N.; Wesson, R.; Reyad, A.; Naqvi, F.F.; Ostrander, D.; et al. Direct-Acting Antiviral Prophylaxis in Kidney Transplantation From Hepatitis C Virus-Infected Donors to Noninfected Recipients: An Open-Label Nonrandomized Trial. Ann. Intern. Med. 2018, 168, 533-540. [CrossRef] [PubMed]

32. Woolley, A.E.; Singh, S.K.; Goldberg, H.J.; Mallidi, H.R.; Givertz, M.M.; Mehra, M.R.; Coppolino, A.; Kusztos, A.E.; Johnson, M.E.; Chen, K.; et al. Heart and Lung Transplants from HCV-Infected Donors to Uninfected Recipients. N. Engl. J. Med. 2019, 380, 1606-1617. [CrossRef] [PubMed]

33. Wadei, H.M.; Pungpapong, S.; Cortese, C.; Alexander, M.P.; Keaveny, A.P.; Yang, L.; Taner, C.B.; Croome, K.P. Transplantation of HCV-infected organs into uninfected recipients: Advance with caution. Am. J. Transplant. 2019, 19, 960-961. [CrossRef] [PubMed]

34. Abdelbasit, A.; Hirji, A.; Halloran, K.; Weinkauf, J.; Kapasi, A.; Lien, D.; Nagendran, J.; Doucette, K. Lung transplantation from hepatitis $C$ viremic donors to uninfected recipients. Am. J. Respir. Crit. Care Med. 2018, 197, 1492-1496. [CrossRef] [PubMed]

35. Schlendorf, K.H.; Zalawadiya, S.; Shah, A.S.; Wigger, M.; Chung, C.Y.; Smith, S.; Danter, M.; Choi, C.W.; Keebler, M.E.; Brinkley, D.M.; et al. Early outcomes using hepatitis C-positive donors for cardiac transplantation in the era of effective direct-acting anti-viral therapies. J. Heart Lung Transplant. 2018, 37, 763-769. [CrossRef]

36. Hill, A.; Khoo, S.; Fortunak, J.; Simmons, B.; Ford, N. Minimum costs for producing hepatitis C direct-acting antivirals for use in large-scale treatment access programs in developing countries. Clin. Infect. Dis. Off. Publ. Infect. Dis. Soc. Am. 2014, 58, 928-936. [CrossRef] [PubMed]

37. The Use of Hepatitis C Positive Kidneys in Hepatitis C Negative Kidney Transplant Recipients. University of Pittsburgh Medical Center, 2019. Available online: https://clinicaltrials.gov/ct2/show/NCT03809533 (accessed on 17 August 2019).

38. The Use of Hepatitis C Positive Livers in Hepatitis C Negative Liver Transplant Recipients. University of Pittsburgh Medical Center, 2019. Available online: https://clinicaltrials.gov/ct2/show/NCT03819322 (accessed on 17 August 2019).

39. Expanding the Pool in Orthotopic Heart Transplantation. University of Pittsburgh Medical Center, 2019. Available online: https://clinicaltrials.gov/ct2/show/NCT03222531 (accessed on 17 August 2019).

40. Cotter, T.G.; Paul, S.; Sandıkçı, B.; Couri, T.; Bodzin, A.S.; Little, E.C.; Sundaram, V.; Charlton, M. Increasing Utilization and Excellent Initial Outcomes Following Liver Transplant of Hepatitis C Virus (HCV)-Viremic Donors Into HCV-Negative Recipients: Outcomes Following Liver Transplant of HCV-Viremic Donors. Hepatology 2019, 69, 2381-2395. [CrossRef]

41. Axelrod, D.A.; Schnitzler, M.A.; Alhamad, T.; Gordon, F.; Bloom, R.D.; Hess, G.P.; Xiao, H.; Nazzal, M.; Segev, D.L.; Dharnidharka, V.R.; et al. The impact of direct-acting antiviral agents on liver and kidney transplant costs and outcomes. Am. J. Transplant. 2018, 18, 2473-2482. [CrossRef] 
42. Cholankeril, G.; Li, A.A.; March, K.L.; Yoo, E.R.; Kim, D.; Snyder, H.; Gonzalez, S.A.; Younossi, Z.M.; Ahmed, A. Improved outcomes in HCV patients following liver transplantation during the era of direct-acting antiviral agents. Clin. Gastroenterol. Hepatol. 2018, 16, 452-453. [CrossRef]

43. Kadatz, M.; Klarenbach, S.; Gill, J.; Gill, J.S. Cost-effectiveness of using kidneys from hepatitis C nucleic acid test-positive donors for transplantation in hepatitis C-negative recipients. Am. J. Transplant. 2018, 18, 2457-2464. [CrossRef]

44. Centers for Disease Control and Prevention. Core Elements of Hospital Antibiotic Stewardship Programs. 2015. Available online: https://www.cdc.gov/antibiotic-use/healthcare/implementation/core-elements.html (accessed on 7 May 2015).

45. Svarovskaia, E.S.; Dvory-Sobol, H.; Parkin, N.; Hebner, C.; Gontcharova, V.; Martin, R.; Ouyang, W.; Han, B.; $\mathrm{Xu}, \mathrm{S}$.; Ku, K.; et al. Infrequent development of resistance in genotype 1-6 hepatitis $\mathrm{C}$ virus-infected subjects treated with sofosbuvir in phase 2 and 3 clinical trials. Clin. Infect. Dis. 2014, 59, 1666-1674. [CrossRef] [PubMed]

46. Tavares, R.; Feldner, A.; Pinho, J.; Malta, F.; Carvalho-Filho, R.; Santana, R.; de Castro, V.; Dastoli, G.; Lima, J.; Ferraz, M. Prevalence of resistance-associated substitutions to direct-acting antiviral agents in hemodialysis and renal transplant patients infected with hepatitis C virus. Infect. Drug Resist. 2018, 11, 1993-2000. [CrossRef] [PubMed]

47. Gendia, M.; Lampertico, P.; Alfieri, C.M.; D’Ambrosio, R.; Gandolfo, M.T.; Campise, M.R.; Fabrizi, F.; Messa, P. Impact of hepatitis $C$ virus and direct acting antivirals on kidney recipients: A retrospective study. Transpl. Int. 2019, 32, 493-501. [CrossRef] [PubMed]

48. Chute, D.F.; Chung, R.T.; Sise, M.E. Direct-acting antiviral therapy for hepatitis C virus infection in the kidney transplant recipient. Kidney Int. 2018, 93, 560-567. [CrossRef] [PubMed]

49. Navarro, D.; Fernández-Ruiz, M.; Aguado, J.M.; Sandonís, V.; Pérez-Romero, P. Going beyond serology for stratifying the risk of CMV infection in transplant recipients. Rev. Med. Virol. 2019, 29, e2017. [CrossRef] [PubMed]

50. Hartmann, A.; Sagedal, S.; Hjelmesæth, J. The Natural Course of Cytomegalovirus Infection and Disease in Renal Transplant Recipients. Transplantation 2006, 82, S15-S17. [CrossRef]

51. Jabs, D.A.; Dunn, J.P.; Enger, C.; Forman, M.; Bressler, N.; Charache, P. Cytomegalovirus retinitis and viral resistance. Prevalence of resistance at diagnosis, 1994. Cytomegalovirus Retinitis and Viral Resistance Study Group. Arch. Ophthalmol. 1996, 114, 809-814. [CrossRef] [PubMed]

52. Limaye, A.P. Ganciclovir-resistant cytomegalovirus in organ transplant recipients. Clin. Infect. Dis. Off. Publ. Infect. Dis. Soc. Am. 2002, 35, 866-872. [CrossRef]

53. Kotton, C.N.; Kumar, D.; Caliendo, A.M.; Huprikar, S.; Chou, S.; Danziger-Isakov, L.; Humar, A. The third international consensus guidelines on the management of cytomegalovirus in solid-organ transplantation. Transplantation 2018, 102, 900-931. [CrossRef]

54. Owers, D.S.; Webster, A.C.; Strippoli, G.F.M.; Kable, K.; Hodson, E.M. Pre-emptive treatment for cytomegalovirus viraemia to prevent cytomegalovirus disease in solid organ transplant recipients. Cochrane Database Syst. Rev. 2013, 2, 1-83. [CrossRef]

55. Gilbert, C.; Boivin, G. Human Cytomegalovirus Resistance to Antiviral Drugs. Antimicrob. Agents Chemother. 2005, 49, 873. [CrossRef] [PubMed]

56. Drew, W.L.; Paya, C.V.; Emery, V. Cytomegalovirus (CMV) resistance to antivirals. Am. J. Transplant. 2001, 1, 307-312. [CrossRef] [PubMed]

57. Cherng, B.P.Z.; Tan, T.T.; Tan, B.H. Resistant cytomegalovirus infection in renal transplant recipients. Proc. Singap. Healthc. 2015, 24, 243-248. [CrossRef]

58. Lischka, P.; Hewlett, G.; Wunberg, T.; Baumeister, J.; Paulsen, D.; Goldner, T.; Ruebsamen-Schaeff, H.; Zimmermann, H. In Vitro and In Vivo Activities of the Novel Anticytomegalovirus Compound AIC246. Antimicrob. Agents Chemother. 2010, 54, 1290-1297. [CrossRef] [PubMed]

59. Goldner, T.; Hewlett, G.; Ettischer, N.; Ruebsamen-Schaeff, H.; Zimmermann, H.; Lischka, P. The Novel Anticytomegalovirus Compound AIC246 (Letermovir) Inhibits Human Cytomegalovirus Replication through a Specific Antiviral Mechanism That Involves the Viral Terminase. J. Virol. 2011, 85, 10884-10893. [CrossRef] [PubMed] 
60. Marschall, M.; Stamminger, T.; Urban, A.; Wildum, S.; Ruebsamen-Schaeff, H.; Zimmermann, H.; Lischka, P. In vitro evaluation of the activities of the novel anticytomegalovirus compound AIC246 (letermovir) against herpesviruses and other human pathogenic viruses. Antimicrob. Agents Chemother. 2012, 56, 1135-1137. [CrossRef]

61. Marty, F.M.; Ljungman, P.; Chemaly, R.F.; Maertens, J.; Dadwal, S.S.; Duarte, R.F.; Haider, S.; Ullmann, A.J.; Katayama, Y.; Brown, J.; et al. Letermovir Prophylaxis for Cytomegalovirus in Hematopoietic-Cell Transplantation. N. Engl. J. Med. 2017, 377, 2433-2444. [CrossRef] [PubMed]

62. Stoelben, S.; Arns, W.; Renders, L.; Hummel, J.; Mühlfeld, A.; Stangl, M.; Fischereder, M.; Gwinner, W.; Suwelack, B.; Witzke, O.; et al. Preemptive treatment of Cytomegalovirus infection in kidney transplant recipients with letermovir: Results of a Phase 2a study. Transpl. Int. 2014, 27, 77-86. [CrossRef]

63. Kaul, D.R.; Stoelben, S.; Cober, E.; Ojo, T.; Sandusky, E.; Lischka, P.; Zimmermann, H.; Rubsamen-Schaeff, H. First report of successful treatment of multidrug-resistant cytomegalovirus disease with the novel anti-CMV compound AIC246. Am. J. Transplant. 2011, 11, 1079-1084. [CrossRef]

64. Turner, N.; Strand, A.; Grewal, D.S.; Cox, G.; Arif, S.; Baker, A.W.; Maziarz, E.K.; Saullo, J.H.; Wolfe, C.R. Use of Letermovir as Salvage Therapy for Drug-Resistant Cytomegalovirus Retinitis. Antimicrob. Agents Chemother. 2019, 63, e02337-18. [CrossRef]

65. Papanicolaou, G.A.; Silveira, F.P.; Langston, A.A.; Pereira, M.R.; Avery, R.K.; Uknis, M.; Wijatyk, A.; $\mathrm{Wu}$, J.; Boeckh, M.; Marty, F.M.; et al. Maribavir for Refractory or Resistant Cytomegalovirus Infections in Hematopoietic-cell or Solid-organ Transplant Recipients: A Randomized, Dose-ranging, Double-blind, Phase 2 Study. Clin. Infect. Dis. 2019, 68, 1255-1264. [CrossRef] [PubMed]

66. Alain, S.; Revest, M.; Veyer, D.; Essig, M.; Rerolles, J.P.; Rawlinson, W.; Mengelle, C.; Huynh, A.; Kamar, N.; Garrigue, I.; et al. Maribavir Use in Practice for Cytomegalovirus Infection in French Transplantation Centers. Transplant. Proc. 2013, 45, 1603-1607. [CrossRef] [PubMed]

67. Strasfeld, L.; Lee, I.; Tatarowicz, W.; Villano, S.; Chou, S. Virologic characterization of multidrug-resistant cytomegalovirus infection in 2 transplant recipients treated with maribavir. J. Infect. Dis. 2010, 202, 104-108. [CrossRef]

68. Winston, D.J.; Saliba, F.; Blumberg, E.; Abouljoud, M.; Garcia-Diaz, J.B.; Goss, J.A.; Clough, L.; Avery, R.; Limaye, A.P.; Ericzon, B.G.; et al. Efficacy and safety of maribavir dosed at $100 \mathrm{mg}$ orally twice daily for the prevention of cytomegalovirus disease in liver transplant recipients: A randomized, double-blind, multicenter controlled trial. Am. J. Transplant. 2012, 12, 3021-3030. [CrossRef] [PubMed]

69. Cobbold, M.; Khan, N.; Pourgheysari, B.; Tauro, S.; McDonald, D.; Osman, H.; Assenmacher, M.; Billingham, L.; Steward, C.; Crawley, C.; et al. Adoptive transfer of cytomegalovirus-specific CTL to stem cell transplant patients after selection by HLA-peptide tetramers. J. Exp. Med. 2005, 202, 379-386. [CrossRef] [PubMed]

70. Walter, E.A.; Greenberg, P.D.; Gilbert, M.J.; Finch, R.J.; Watanabe, K.S.; Thomas, E.D.; Riddell, S.R. Reconstitution of Cellular Immunity against Cytomegalovirus in Recipients of Allogeneic Bone Marrow by Transfer of T-Cell Clones from the Donor. N. Engl. J. Med. 1995, 333, 1038-1044. [CrossRef] [PubMed]

71. Smith, C.; Beagley, L.; Rehan, S.; Neller, M.A.; Crooks, P.; Solomon, M.; Holmes-Liew, C.L.; Holmes, M.; McKenzie, S.C.; Hopkins, P.; et al. Autologous Adoptive T-cell Therapy for Recurrent or Drug-resistant Cytomegalovirus Complications in Solid Organ Transplant Recipients: A Single-arm Open-label Phase I Clinical Trial. Clin. Infect. Dis. Off. Publ. Infect. Dis. Soc. Am. 2019, 68, 632-640. [CrossRef] [PubMed]

72. Doubrovina, E.; Oflaz-Sozmen, B.; Prockop, S.E.; Kernan, N.A.; Abramson, S.; Teruya-Feldstein, J.; Hedvat, C.; Chou, J.F.; Heller, G.; Barker, J.N.; et al. Adoptive immunotherapy with unselected or EBV-specific T cells for biopsy-proven EBV+ lymphomas after allogeneic hematopoietic cell transplantation. Blood 2012, 119, 2644-2656. [CrossRef] [PubMed]

73. Sellar, R.S.; Peggs, K.S. Therapeutic Strategies for Cytomegalovirus Infection in Haematopoietic Transplant Recipients: A Focused Update. Expert Opin. Biol. Ther. 2014, 14, 1121-1126. [CrossRef] [PubMed]

74. Dasari, V.; Schuessler, A.; Smith, C.; Wong, Y.; Miles, J.J.; Smyth, M.J.; Ambalathingal, G.; Francis, R.; Campbell, S.; Chambers, D.; et al. Prophylactic and therapeutic adenoviral vector-based multivirus-specific T-cell immunotherapy for transplant patients. Mol. Ther. Methods Clin. Dev. 2016, 3, 16058. [CrossRef] [PubMed]

75. Blyth, E.; Clancy, L.; Simms, R.; Ma, C.K.; Burgess, J.; Deo, S.; Byth, K.; Dubosq, M.C.; Shaw, P.J.; Micklethwaite, K.P.; et al. Donor-derived CMV-specific T cells reduce the requirement for CMV-directed pharmacotherapy after allogeneic stem cell transplantation. Blood 2013, 121, 3745-3758. [CrossRef] [PubMed] 
76. Shreiner, A.B.; Kao, J.Y.; Young, V.B. The gut microbiome in health and in disease. Curr. Opin. Gastroenterol. 2015, 31, 69. [CrossRef] [PubMed]

77. Turnbaugh, P.J.; Ley, R.E.; Hamady, M.; Fraser-Liggett, C.M.; Knight, R.; Gordon, J.I. The human microbiome project. Nature 2007, 449, 804. [CrossRef] [PubMed]

78. Cho, I.; Blaser, M.J. The human microbiome: At the interface of health and disease. Nat. Rev. Genet. 2012, 13, 260. [CrossRef] [PubMed]

79. Ouwehand, A.C.; Salminen, S.; Arvola, T.; Ruuska, T.; Isolauri, E. Microbiota Composition of the Intestinal Mucosa: Association with Fecal Microbiota? Microbiol. Immunol. 2004, 48, 497-500. [CrossRef] [PubMed]

80. Green, G.L.; Brostoff, J.; Hudspith, B.; Michael, M.; Mylonaki, M.; Rayment, N.; Staines, N.; Sanderson, J.; Rampton, D.S.; Bruce, K.D. Molecular characterization of the bacteria adherent to human colorectal mucosa. J. Appl. Microbiol. 2006, 100, 460-469. [CrossRef] [PubMed]

81. Zoetendal, E.G.; von Wright, A.; Vilpponen-Salmela, T.; Ben-Amor, K.; Akkermans, A.D.L.; de Vos, W.M. Mucosa-associated bacteria in the human gastrointestinal tract are uniformly distributed along the colon and differ from the community recovered from feces. Appl. Environ. Microbiol. 2002, 68, 3401-3407. [CrossRef]

82. Thomas, S.; Izard, J.; Walsh, E.; Batich, K.; Chongsathidkiet, P.; Clarke, G.; Sela, D.A.; Muller, A.J.; Mullin, J.M.; Albert, K.; et al. The host microbiome regulates and maintains human health: A primer and perspective for non-microbiologists. Cancer Res. 2017, 77, 1783-1812. [CrossRef]

83. Carding, S.; Verbeke, K.; Vipond, D.T.; Corfe, B.M.; Owen, L.J. Dysbiosis of the gut microbiota in disease. Microb. Ecol. Health Dis. 2015, 26, 26191. [CrossRef]

84. DeGruttola, A.K.; Low, D.; Mizoguchi, A.; Mizoguchi, E. Current understanding of dysbiosis in disease in human and animal models. Inflamm. Bowel Dis. 2016, 22, 1137-1150. [CrossRef]

85. Nataatmadja, M.; Cho, Y.; Campbell, K.; Johnson, D.W. The Roles of Indoxyl Sulphate and p-Cresyl Sulphate in Patients with Chronic Kidney Disease: A Review of Therapeutic Options. In Chronic Kidney Disease-from Pathophysiology to Clinical Improvements; IntechOpen, Thomas Rath: London, UK, 2017; pp. 181-197.

86. Rossi, M.; Johnson, D.W.; Morrison, M.; Pascoe, E.M.; Coombes, J.S.; Forbes, J.M.; Szeto, C.C.; McWhinney, B.C.; Ungerer, J.P.; Campbell, K.L. Synbiotics Easing Renal Failure by Improving Gut Microbiology (SYNERGY): A Randomized Trial. Clin. J. Am. Soc. Nephrol. 2016, 11, 223-231. [CrossRef]

87. Ahmad, S.; Bromberg, J. Current status of the microbiome in renal transplantation. Curr. Opin. Nephrol. Hypertens. 2016, 25, 570. [CrossRef] [PubMed]

88. Meier, R.P.; Andrey, D.O.; Sun, P.; Niclauss, N.; Bédat, B.; Demuylder-Mischler, S.; Borot, S.; Benhamou, P.Y.; Wojtusciszyn, A.; Buron, F.; et al. Pancreas preservation fluid microbial contamination is associated with poor islet isolation outcomes-a multi-centre cohort study. Transpl. Int. 2018, 31, 917-929. [CrossRef] [PubMed]

89. Sharma, A.K.; Smith, G.; Smith, D.; Sinha, S.; Rustom, R.; Sells, R.A.; Hammad, A.; Bakran, A. Clinical outcome of cadaveric renal allografts contaminated before transplantation. Transpl. Int. 2005, 18, 824-827. [CrossRef] [PubMed]

90. Fricke, W.F.; Maddox, C.; Song, Y.; Bromberg, J.S. Human Microbiota Characterization in the Course of Renal Transplantation. Am. J. Transplant. 2014, 14, 416-427. [CrossRef] [PubMed]

91. Falony, G.; Joossens, M.; Vieira-Silva, S.; Wang, J.; Darzi, Y.; Faust, K.; Kurilshikov, A.; Bonder, M.J.; Valles-Colomer, M.; Vandeputte, D.; et al. Population-level analysis of gut microbiome variation. Science 2016, 352, 560-564. [CrossRef] [PubMed]

92. Zhernakova, A.; Kurilshikov, A.; Bonder, M.J.; Tigchelaar, E.F.; Schirmer, M.; Vatanen, T.; Mujagic, Z.; Vila, A.V.; Falony, G.; Vieira-Silva, S.; et al. Population-based metagenomics analysis reveals markers for gut microbiome composition and diversity. Science 2016, 352, 565-569. [CrossRef]

93. Sawas, T.; Al Halabi, S.; Hernaez, R.; Carey, W.D.; Cho, W.K. Patients Receiving Prebiotics and Probiotics Before Liver Transplantation Develop Fewer Infections Than Controls: A Systematic Review and Meta-Analysis. Clin. Gastroenterol. Hepatol. 2015, 13, 1567-1574. [CrossRef]

94. Kothari, D.; Patel, S.; Kim, S.K. Probiotic supplements might not be universally-effective and safe: A review. Biomed. Pharmacother. 2019, 111, 537-547. [CrossRef]

95. Kim, P.; Gadani, A.; Abdul-Baki, H.; Mitre, R.; Mitre, M. Fecal microbiota transplantation in recurrent Clostridium difficile infection: A retrospective single-center chart review. JGH Open 2019, 3, 4-9. [CrossRef] 
96. Shogbesan, O.; Poudel, D.R.; Victor, S.; Jehangir, A.; Fadahunsi, O.; Shogbesan, G.; Donato, A. A systematic review of the efficacy and safety of fecal microbiota transplant for Clostridium difficile infection in immunocompromised patients. Can. J. Gastroenterol. Hepatol. 2018, 2018, 1394379. [CrossRef] [PubMed]

97. Kakihana, K.; Fujioka, Y.; Suda, W.; Najima, Y.; Kuwata, G.; Sasajima, S.; Mimura, I.; Morita, H.; Sugiyama, D.; Nishikawa, H.; et al. Fecal microbiota transplantation for patients with steroid-resistant acute graft-versus-host disease of the gut. Blood 2016, 128, 2083-2088. [CrossRef] [PubMed]

(c)

(C) 2019 by the authors. Licensee MDPI, Basel, Switzerland. This article is an open access article distributed under the terms and conditions of the Creative Commons Attribution (CC BY) license (http://creativecommons.org/licenses/by/4.0/). 